Kapata Arkeologi, 12(1), 59-70

ISSN (cetak): 1858-4101

ISSN (elektronik): 2503-0876

http://kapata-arkeologi.kemdikbud.go.id

\title{
SITUS MAKAM-MAKAM KUNA DI KABUPATEN KUNINGAN BAGIAN TIMUR: Kaitannya dengan Religi
}

\section{Site of Ancient Tombs in the Eastern Part of Kuningan Regency: Relation to Religion}

\author{
Effie Latifundia \\ Balai Arkeologi Jawa Barat - Indonesia \\ Jl. Raya Cinunuk km.17, Cileunyi, Bandung \\ yunda_effie@yahoo.com
}

Naskah diterima: 16/09/2016; direvisi: 18/11 - 05/12/2016; disetujui: 15/12/2016

Publikasi ejurnal: 30/12/2016

\begin{abstract}
Site of ancient tombs in the eastern part of Kuningan regency, West Java shows the indication of religion and tradition. This is reflected in the lives of the communities that adopted the practice of honoring the well known figures of the past. The graves of these famous figures such as religious leaders, community leaders, ancestors receive certain treatments. The ancient tombs have been seen as the sacred site, as well as an object of pilgrimage, and used as the media to ask for something to include offerings. This paper aims to uncover these ancient tombs with their religious background. The data have been collected by a survey to gain information and describe the forms of ancient tombs. The results showed that although Islam flourishes, the belief in ancestors as religion before Islam still ongoing and sustained. Essentially any form of tribute to the ancestors is a continuation of the megalithic tradition in prehistoric times. It was concluded, at the time of the influence of Islamic religious life particularly associated with death there is a reduction in pre-Islamic era.
\end{abstract}

Keywords: religion, ancient tombs, pilgrimage tomb

\begin{abstract}
Abstrak
Situs makam-makam kuna di Kabupaten Kuningan bagian timur, Jawa Barat menunjukkan adanya unsur religi dan tradisi. Hal ini tercermin dalam kehidupan sebagian masyarakat adanya suatu konsep penghormatan kepada tokoh yang sudah meninggal dunia. Makam para tokoh terkenal seperti pemuka agama, tokoh masyarakat, leluhur mendapat perlakuan tertentu. Makam-makam kuna tersebut dikeramatkan, sebagai objek ziarah, dan dijadikan media meminta sesuatu dengan dilengkapi sesaji. Tulisan ini bertujuan mengungkap makam-makam kuna berlatar religius. Metode pengumpulan data dilakukan dengan survei untuk mengumpulkan informasi dan mendeskripsikan bentuk-bentuk makam kuno. Hasil penelitian menunjukkan meskipun Islam berkembang namun kepercayaan terhadap leluhur sebagai religi sebelum Islam masih terus berlangsung dan dipertahankan. Secara esensial adanya bentuk penghormatan kepada leluhur merupakan kelanjutan tradisi megalitik pada masa prasejarah. Disimpulkan, pada masa pengaruh Islam kehidupan religi khususnya yang berkaitan dengan kematian terdapat suatu reduksi dengan masa pra Islam.
\end{abstract}

Kata Kunci: religi, makam kuna, ziarah makam

\section{PENDAHULUAN}

Religi bagian dari kebudayaan sudah berkembang di Indonesia sejak masa pra Islam. Unsur utama religi adalah keyakinan atau kepercayaan bagi penganutnya. Keyakinan akan rasa percaya adanya dunia gaib, ide tentang
"Tuhan," hari kemudian, percaya akan adanya kekuatan supernatural, serta berbagai macam hal yang dapat menimbulkan rasa percaya yang diyakini (Hafid, 2013:10). Kajian religi dalam arkeologi menitikberatkan perhatian pada sistem kepercayaan masyarakat masa lampau 
melalui pengkajian aspek bentuk terhadap benda-benda material yang ditinggalkannya. Oleh karena itu keterangan mengenai bentuk artefak, keletakan artefak dan asosiasi tipe-tipe artefak dalam suatu situs merupakan data dasar yang dapat digunakan untuk studi religi dalam arkeologi. Pengenalan ciri-ciri religi terhadap data arkeologi yang terbatas, akan dapat mengimbangi untuk menjawab perilaku masyarakat pada waktu itu yang sudah tidak dapat diketahui lagi (Prasetyo, 2004: 9). Religi terbentuk oleh sejumlah unsur, yakni keyakinan atau kepercayaan, upacara, kelompok penghayat serta petugas khusus, emosi keagamaan dan peralatan serta perlengkapan upacara, semua unsur tersebut saling terkait (Radam, 2001: 35).

Salah satu fungsi religi adalah untuk mengurangi kegelisahan karena religi dapat menerangkan hal-hal yang tidak dapat dipahami oleh manusia. Melalui religi manusia bisa mendapat ketenangan untuk menghadapi dan menjawab hal-hal di luar kemampuan pikirannya (Prasetyo, 2004: 3). Keterbatasan akal manusia untuk memenuhi kebutuhan hidup jasmani dan rohani biasanya dilakukan dengan cara ilmu ghaib/mistis atau spiritual.

Pada masa pengaruh Islam makammakam yang dipandang sebagai tokoh (raja, wali, pemuka agama, tokoh masyarakat, leluhur) mendapat perlakuan khusus. Tokohtokoh kharisma yang dimitoskan makamnya dijadikan objek ziarah. Hal tersebut terjadi karena masyarakat Islam sangat menghormati orang suci dan makamnya dianggap keramat. Makam atau areal makam akan menjadi lebih keramat setelah ulama/tokoh Islam yang kharismatik dikuburkan ditempat itu. Masyarakat beranggapan bahwa para ulama/tokoh Islam mampu memimpin dan mengantar kejenjang yang lebih baik di bidang sosial dan spiritual, sehingga tradisi ziarah makam terus berkembang. Tokoh kharismatik makamnya dikeramatkan untuk dipuja, dihormati, dikagumi dan diperindah dengan bentuk dan hiasan penanda makam yang beraneka ragam. Kemudian makam diberi cungkup, kelambu, tembok keliling dan sebagai objek peziarah (Suhadi dan Halina Hambali 1994/1995:29).

Makam yang dikeramatkan merupakan tempat bersemayamnya arwah leluhur atau dewa-dewi dan kekuatan gaib, sehingga tempat tersebut dijadikan situs religius (Rosmana, 2009: 244). Menziarahi makam keramat merupakan suatu kebutuhan hidup yang mencakup kebutuhan jasmani dan rohani. Selanjutnya pada makam-makam keramat masyarakat melakukan tradisi dan ritual dengan maksud agar hubungan baik dengan arwah leluhur terus terjaga dan berlangsung. Ritual keagamaan yang dilaksanakan oleh sekelompok masyarakat sebagai bagian dari wujud kebudayaan memiliki makna dan simbol yang mencirikan kekhasan dari kebudayaan yang bersangkutan. Kekhasan dari suatu unsur kebudayaan ini kemudian disimbolkan sebagai bentuk identitas masyarakat pendukung kebudayaan tersebut (Adeng, 2012: 21). Akibatnya sejumlah makam dikeramatkan dan secara keliru dijadikan media meminta sesuatu (Ambary,1991:2-3). Semua kegiatan tersebut menggambarkan emosi keagamaan. Emosi keagamaan adalah suatu getaran menghinggapi seseorang dalam hidupnya pada suatu waktu. Emosi keagamaan ada di setiap kelakuan serba religi, sehingga timbulnya sikap keramat (1984: 239).

Demikian halnya sebagian masyarakat yang berada di beberapa desa di Kecamatan Cibingbin dan Cibeureum. Masyarakat tersebut berada di wilayah Kabupaten Kuningan bagian timur di Jawa Barat yang secara administrasif dibatasi oleh sebelah utara Kabupaten Cirebon, di sebelah timur Kabupaten Brebes,di sebelah selatan Kabupaten Cilacap, di sebelah Barat Kecamatan Cibeureum Kabupaten Kuningan. Secara geografis wilayah Kabupaten Kuningan bagian timur, Jawa Barat ini berada di perbatasan langsung dengan Kabupaten Brebes, Jawa Tengah. Makam-makam kuna dan petilasan di keramatkan. Makam tokoh agama, leluhur masa hidupnya memiliki karisma menjadi tempat ziarah. Di areal makam pada waktu-waktu tertentu dijadikan sebagai pusat kegiatan ritual, yaitu upacara persembahan dengan membawa sesaji.

Berkaitan dengan makam-makam kuna tersebar di beberapa kawasan Cibingbin dan Cibeureum wilayah Kabupaten Kuningan bagian timur muncul permasalahan, yaitu identifikasi bentuk penanda makam dan identifikasi makam-makam kuna yang bercirikan tinggalan religius. Permasalahan ini meupakan kajian yang sangat umum dalam penelitian arkeologi Islam, mengingat pada 
umumnya tradisi pra Islam di banyak daerah di Nusantara terus berlangsung dan bertahan walaupun Islam sudah berkembang termasuk wilayah Kabupaten Kuningan bagian timur. Persentuhan Islam dengan budaya lokal masih sangat kuat di tengah-tengah kehidupan sebagian masyarakatnya. Pada hari-hari tertentu masyarakat mengadakan upacara membersihkan makam, membawa sesaji dan terjalin kontak langsung dengan si mati melalui ziarah. Penelitian ini bertujuan untuk mengungkap makam-makam kuna berlatar religius di Kabupaten Kuningan bagian barat di Jawa Barat.

\section{METODE}

Metode penelitian ini dilakukan melalui survei untuk mengumpulkan dan mendeskripsikan data arkeologi berwujud bentuk, keletakan makam yang berhubungan dengan religi secara umum. Selanjutnya informasi lain terkait fenomena yang dikaji melalui kepustakaan dan wawancara dengan masyarakat setempat. Kegiatan pengumpulan data dilakukan pada tahun 2015.

\section{HASIL DAN PEMBAHASAN \\ Situs Makam-makam Kuna \\ Situs Pangeran Pasalisingan}

Situs Pangeran Pasalisingan terdapat di Kampung Cibodas, Desa Cipondok, Kecamatan Cibingbin. Situs Pangeran Pasalisingan terletak di areal perbukitan cukup terjal. Perbukitan makam dibatasi ruas jalan desa di sebelah utara, sawah di sebelah timur dan selatan, serta aliran Sungai Cikamuning di sebelah barat. Situs Pangeran Pasalisingan menurut keterangan masyarakat setempat merupakan petilasan dilengkapi dengan penanda makam berupa nisan dan jirat.

Nisan berjumlah dua berupa batu tegak (menhir) tidak beraturan bahan batu alam berorientasi timur laut-barat daya. Nisan bagian timur laut berukuran tinggi $60 \mathrm{~cm}$, lebar $25 \mathrm{~cm}$, sedangkan nisan bagian barat daya berukuran tinggi $56 \mathrm{~cm}$, lebar $18 \mathrm{~cm}$. Makam memakai jirat gundukan batu- batu alam, berbentuk persegi berukuran panjang $350 \mathrm{~cm}$ dan lebar $320 \mathrm{~cm}$.

Menurut keterangan masyarakat situs Pangeran Pasalisingan dikeramatkan dan sering didatangi pengunjung untuk tujuan bertapa. Peziarah yang datang ke makam tersebut terutama dari luar desa dengan maksud-maksud tertentu. Di areal situs ditemukan sesaji yang di bawa peziarah berupa kelapa muda, rokok, dan air kopi.

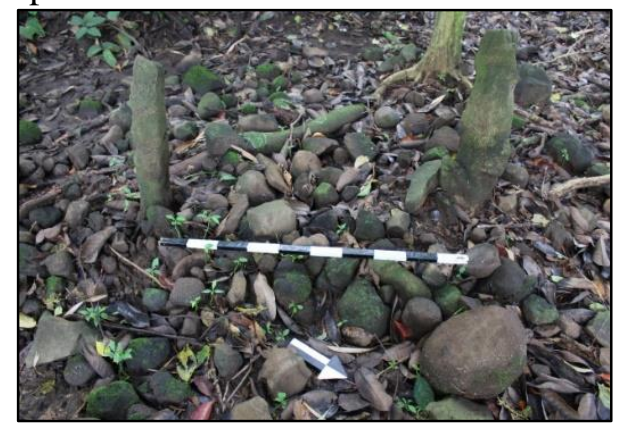

Gambar 1. Situs Pangeran Pasalisingan, Desa Cipondok, Kec. Cibingbin

(Sumber: Balai Arkeologi Bandung, 2015)

\section{Situs Langkoyang}

Situs Langkoyang terdapat di Desa Cisaat, Kecamatan Cibingbin. Situs Langkoyang terletak sangat jauh dari permukiman penduduk berada di areal perbukitan dikelilingi pohon-pohon besar dan perdu. Unsur megalitik terlihat pada penanda makam berupa jirat yang terbuat dari susunan batu-batu alam berbentuk empat persegi panjang. Sementara jirat makam terdiri gundukan tanah yang dikelilingi susunan batu, dengan jirat yang tampak ditinggikan.

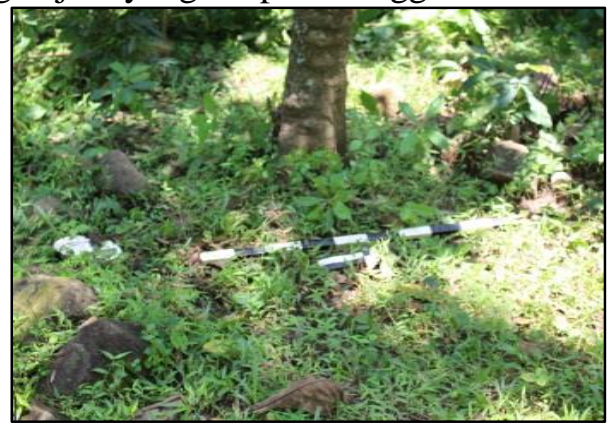

Gambar 2. Situs Langkoyang, Desa Cisaat, Kec. Cibingbin

(Sumber: Balai Arkeologi Bandung, 2015)

Situs Langkoyang merupakan petilasan dan dikeramat oleh masyarakat setempat. Menurut keterangan masyarakat situs Langkoyang sering dikunjungi pendatang dari luar desa dengan tujuan bertapa dengan mempunyai maksud tertentu. Kebanyakan pengunjung yang datang ke situs Langkoyang melalui petunjuk dalam mimpi. Sekarang ini lokasi situs terlihat kurang bersih ditumbuhi rerumputan, setelah ditinggal wafat juru kunci 
situs. Menurut cerita lisan, bahwa dahulu areal situs merupakan bekas lokasi tempat peristirahatan Pangeran Diponegoro dan pengikutnya dalam perjalanannya ke Puncak Manik (tempat keramat) di Desa Cimulya di wilayah Kuningan. Di areal situs ditemukan bekas-bekas sesaji yang di bawa oleh pengunjung.

\section{Situs Buyut Panjang}

$\begin{array}{ccc}\text { Situs } & \text { Buyut Panjang terdapat di } \\ \text { Kampung } & \text { Gembol, Desa } & \text { Sumurwiru, }\end{array}$ Kecamatan Cibeureum. Situs Buyut Panjang terletak di areal pemakaman umum Desa Sumurwiru. Makam Buyut Panjang berorientasi utara-selatan, dengan penanda nisan batu tegak (menhir) berjumlah dua, bahan batuan alam dengan bentuk lonjong tidak beraturan. Batu tegak bagian utara berukuran tinggi $29 \mathrm{~cm}$, lebar $15 \mathrm{~cm}$. Batu tegak bagian selatan berukuran tinggi $43 \mathrm{~cm}$, lebar $20 \mathrm{~cm}$. Jirat bahan batu-batu alam bentuk empat persegi berukuran panjang $5 \mathrm{~m}$ dan lebar $2,9 \mathrm{~m}$. Buyut panjang leluhur masyarakat setempat, dan dipercaya sebagai tokoh penyebar Islam pernah berguru di Pasantren Gunung Jawa, Karangkencana Kuningan. Menurut cerita lisan, dinamakan Buyut Panjang pada masa hidupnya memiliki badan yang besar dengan tubuh yang sangat panjang atau tinggi. Makam dikeramatkan dan sering dikunjungi peziarah terutama yang datang dari luar desa, dengan maksud dan tujuan tertentu.

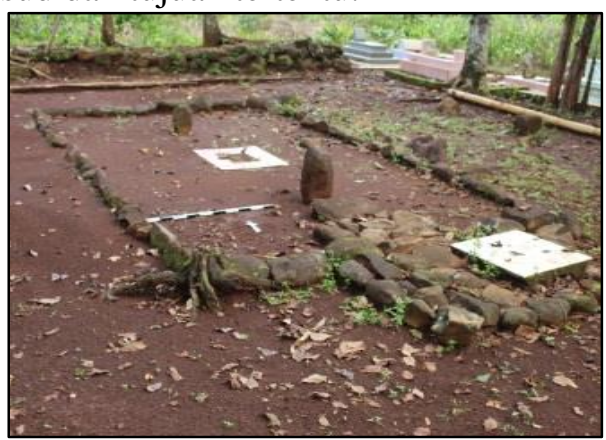

Gambar 3. Nisan Buyut Panjang di Desa Sumurwiru, Kec. Cibereum.

(Sumber: Balai Arkeologi Bandung, 2015)

\section{Situs Paserean}

Situs Pasarean terdapat di Desa Bantarpanjang, Kecamatan Cibingbin. Situs Pasarean terletak di areal perbukitan dikelilingi perkebunan pohon jati jauh dari pemukiman penduduk. Areal situs sekarang ini milik perhutani. Situs Pasarean merupakan petilasan yang dikeramatkan masyarakat setempat. Situs berorientasi timur laut-barat daya. Ditandai adanya tatanan batu alam membentuk melingkar. Lebih kurang $390 \mathrm{~cm}$ kearah barat laut situs Pasaren terdapat monolit berukuran tinggi $175 \mathrm{~cm}$, diameter atas $100 \mathrm{~cm}$, dan diameter bawah $180 \mathrm{~cm}$. Menurut cerita dalam masyarakat bahwa situs Pasarean sangat angker karena sering mengeluarkan suara-suara aneh baik di siang hari maupun malam hari yang sering terdengar oleh masyarakat desa. Dahulu lokasi situs Pasarean tempat pertemuan para ulama atau kiai khusus berdiskusi membahas tentang penyebaran agama Islam. Para kiai yang berkumpul di lokasi ini datang dari segala penjuru baik dari Cirebon maupun dari Jawa. Situs Pasarean hingga sekarang masih sering dikunjungi pendatang dari luar daerah dengan maksud dan tujuan tertentu, dan di areal situs ditemukan bekas sesaji terutama kelapa muda dan rokok.

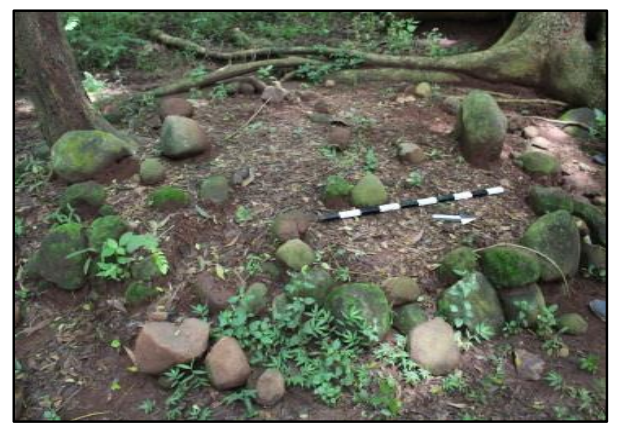

Gambar 4. Situs Pasarean, Desa Cimara, Kec. Cibingbin

(Sumber: Balai Arkeologi Bandung, 2015)

\section{Situs Suranggadipa}

Situs Suranggadipa terdapat di areal makam umum Astana Gajah berada di pinggir jalan raya Desa Sukaharja, Kecamatan Cibingbin. Situs merupakan makam Suranggadipa penanda makam ditandai dua nisan pipih berorientasi utara-selatan. Nisan bagian utara dan bagian selatan mempunyai ukuran yang sama yaitu tinggi $56 \mathrm{~cm}$, lebar 38 $\mathrm{cm}$, dan jarak antar nisan $70 \mathrm{~cm}$. Pada bagian badan nisan terdapat hiasan berupa lingkaran (mendalion) bertuliskan arab gundul, dan segitiga serta sulur-sulur. Jirat terbuat dari bata berterap 6 , berdenah empat persegi panjang dan semakin ke atas semakin mengecil. Jirat paling bawah berukuran panjang $163 \mathrm{~cm}$, lebar $80 \mathrm{~cm}$, dan jirat paling atas berukuran panjang $131 \mathrm{~cm}$, 
lebar $50 \mathrm{~cm}$. Makam Suranggadipa terdapat dalam cungkup setengah permanen atap genteng, lantai ubin, dinding kayu berukuran $575 \times 535 \mathrm{~cm}$. Menurut cerita lisan, Buyut Suranggadipa seorang petapa datang dari Luragung (Kuningan) memiliki ilmu sakti yang termashur dan manjur dalam mengobati segala macam penyakit. Suranggadipa merupkan tokoh penyebar Islam hingga akhir hayatnya berada di Cibingbin. Makam dikeramatkan dan sering dikunjungi peziarah yang datang dari wilayah Kuningan dan sekitarnya. Di areal makam masih ditemukan bekas sesaji yang dibawa pengunjung.

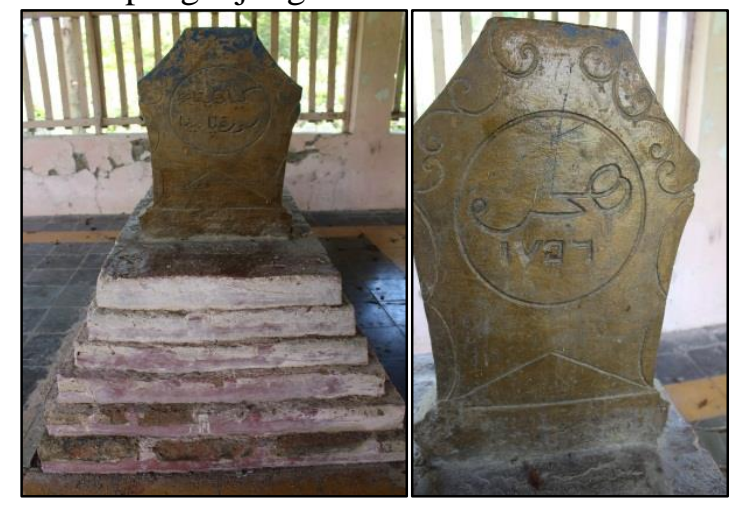

Gambar 5. Nisan Makam Suranggadipa

(Sumber: Balai Arkeologi Bandung, 2015)

\section{Situs Cipari}

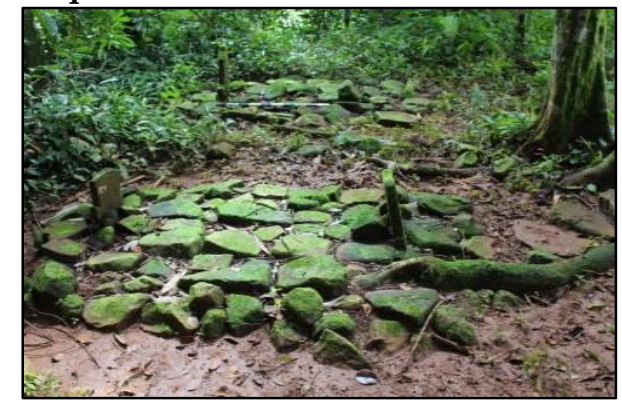

Gambar 6. Situs Cipari, Desa Cimara, Kec. Cibeureum

(Sumber: Balai Arkeologi Bandung, 2015)

Situs Cipari terdapat di Desa Cimara, Kecamatan Cibeureum. Situs Cipari terletak di areal perbukitan cukup tinggi dan sangat jauh dari pemukiman penduduk. Di areal situs terdapat dua makam, yaitu makam Buyut Jaksa dan makam Buyut Saketi. Menurut keterangan masyarakat, kedua tokoh tersebut datang ke wilayah tersebut menyebarkan agama Islam.. Kedua makam berorientasi utara-selatan yang dilengkapi penanda makam berupa jirat dan nisan. Makam Buyut Jaksa ditandai dua nisan pipih masing-masing berukuran, sebelah utara berukuran tinggi $32 \mathrm{~cm}$, lebar $20 \mathrm{~cm}$, sedangkan nisan selatan berukuran tinggi 35, kebar 25 . Makam tersebut berjirat batu-batu alam bentuk empat persegi berukuran panjang $205 \mathrm{sm}$ dan lebar $150 \mathrm{~cm}$.

Makam Buyut Saketi terdapat di sebelah timur makam Buyut Jaksa ditandai dua nisan pipih berukutan tinggi $48 \mathrm{~cm}$, lebar $19 \mathrm{~cm}$, dan nisan selatan kondisi patah. Jirat bahan batu alam bentuk empat persegi panjang berukuran panjang $235 \mathrm{~cm}$ dan lebar $130 \mathrm{~cm}$. Pada bagian badan nisan terdapat hiasan berupa lingkaran (mendalion), dan sulur-sulur. Makam dikeramatkan dan sering dikunjungi para peziarah terutama yang datang dari luar desa dengan maksud tertentu.

\section{Situs Raksapati}

Situs Raksapati terdapat di Desa Tarikolot jauh dari pemukiman penduduk terletak $20 \mathrm{~m}$ arah selatan dari Sungai Cikarok. Untuk menuju lokasi situs Raksapati pengunjung terlebih dahulu menyebrangi Sungai Cikorok yang tidak mempunyai jembatan penyebrangan. Penanda makam Raksapati di tandai dua nisan batu pipih tidak beraturan berorientasi timur laut-barat daya. Batu pipih bagian timur laut berukuran tinggi $23 \mathrm{~cm}$. Lebar $37 \mathrm{~cm}$, sedangkan bagian barat daya berukuran tinggi $16 \mathrm{~cm}$, lebar $22 \mathrm{~cm}$ dan jarak antar nisan $90 \mathrm{~cm}$.

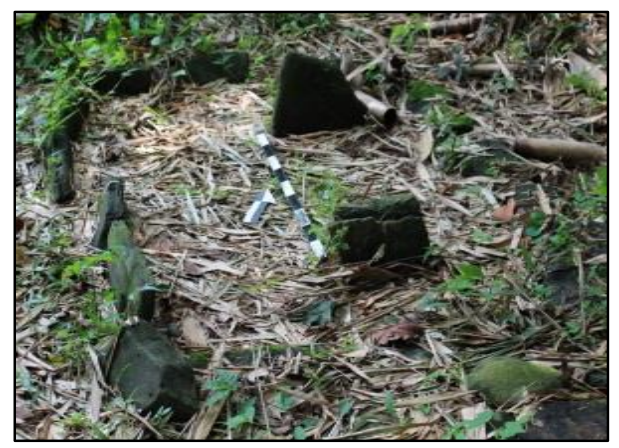

Gambar 7. Makam Raksapati, Desa tarikolot, Kec. Cibeureum

(Sumber: Balai Arkeologi Bandung 2015)

Jirat berbentuk empat persegi terbuat dari batu-batu lempengan pipih berukuran panjang $210 \mathrm{sm}$, dan lebar $130 \mathrm{~cm}$. Masyarakat mengatakan makam Raksapati cukup angker. Areal makam terasa sangat gelap dikelilingi pohon bambu. Makam dikeramatkan oleh masyarakat setempat dan sering dikunjungi 
pendatang dari luar desa atau daerah berdasarkan petunjuk dalam mimpi.

\section{Situs Cipariuk}

Situs Cipariuk terdapat di Desa Randusari, Kecamatan Cibereum terletak di lereng perbukitan Cipariuk yang membujur dari barat daya- timur laut. Situs merupakan kompleks makam-makam kuna terletak jauh dari pemukiman penduduk. Berdasarkan hasil temuan tinggalan budaya situs merupakan punden berundak berteras 7 .

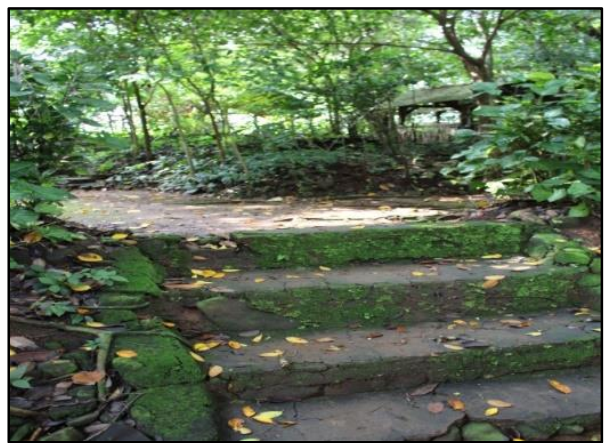

Gambar 8. Tangga menuju teras -1 pada situs Cipariuk

(Sumber: Balai Arkeologi Bandung 2015)

Di kompleks makam Cipariuk terdapat lima makam kuna, menggunakan penanda makam berupa jirat dan nisan dan diberi cungkup. Kelima makam merupakan tokoh penyebar Islam:

1. Makam Jalasutra, terletak pada teras-7 diberi cungkup dikelilingi pagar bambu, dan penanda makam ditandai dua nisan batu alam bentuk bulat berorientasi utara-selatan.

2. Makam Cibinio, terletak pada teras-6 penanda makam berupa dua nisan batu alam berorientasi utara-selatan. Berjirat batu-batu alam berukuran panjang $290 \mathrm{~cm}$, dan lebar $200 \mathrm{~cm}$. Menurut cerita masyarakat bahwa nama Desa Cibingbin terinspirasi dari nama Cibinio.

3. Makam Naladita/Buyut Kiai masih terletak pada teras-6, dengan penanda makam ditandai dua nisan batu alam bulat. Jirat batu-batu alam berukuran panjang $290 \mathrm{~cm}$, dan lebar $200 \mathrm{~cm}$.

4. Makam Ditanala, terletak di teras-5, dengan penanda makam ditandai dua nisan batu alam berorientasi utara-selatan.

5. Makam Buyut Ratu Amalia, terletak pada teras -4 , dengan penanda makam berupa dua nisan batu alam bentuk pipih, berorientasi utara-selatan dan berjirat bahan lempengan batu-batu alam berukuran panjang $200 \mathrm{~cm}$, dan lebar $150 \mathrm{~cm}$.

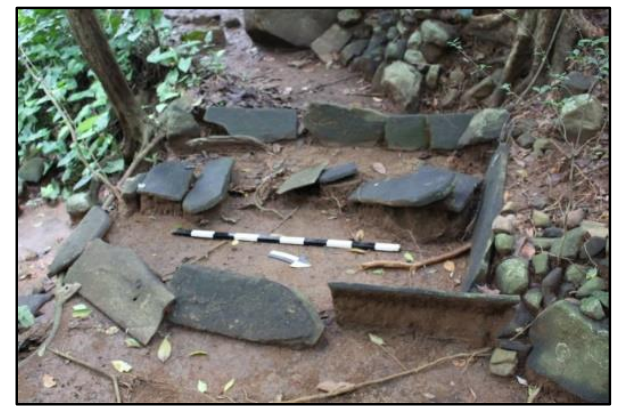

Gambar 9. Makam Ratu Amalia di situs Cipariuk (Sumber: Balai Arkeologi Bandung 2015)

6. Makam Wiradita, terletak pada teras-4, di beri cunkup, dengan penanda makam berupa dua nisan batu bulat.

7. Makam Siti Rahayati, ditandai penanda makam berupa dua nisan, dan jirat batu-batu alam berukuran panjang $320 \mathrm{~cm}$, lebar 180 $\mathrm{cm}$.. Siti Rahayati menurut penuturan juru kunci berasal dari Luragung-Kuningan.

Kompleks makam menggambarkan situs prasejarah terdapat monolit dan punden berundak. Kompleks makam di keramatkan dan sering dikunjungi peziarah yang datang dari berbagai daerah di dalam dan diluar Jawa Barat. Kompleks makam terlihat gelap banyak ditumbuh tanaman keras dengan pohon-pohon besar.

\section{Situs Kompleks Walangsungsang}

Situs Walangsungsang berada di Kampung Wanaasih, Desa Randusari, Kecamatan Cibeureum terletak di perbukitan. Komplek makam Walasungsang ini terdiri dari lima teras dengan luas sekitar $300 \mathrm{~m} 2$. Makam tertinggi terdapat di teras- 5 di bagian barat laut dan berupa kubur papan batu dengan nisan batu kali.

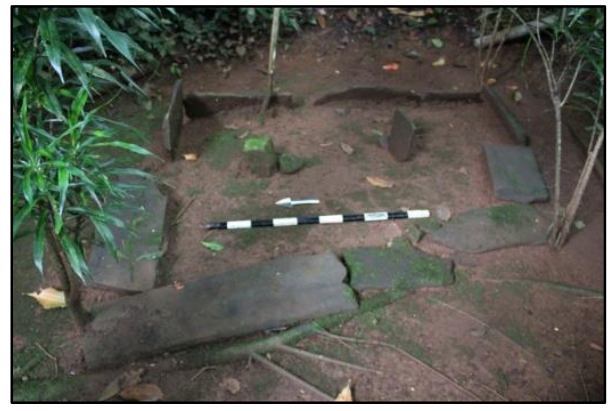

Gambar 10. Makam di teras-5 situs Walisungsang, (Sumber: Balai Arkeologi Bandung, 2015) 
Petilasan Walangsungsang terdapat di teras ke-4 dan sudah ditembok serta diberi cungkup. Petilasan Walangsungsang sudah diperbaharui dan diberi cungkup. Cungkup berfungsi terutama untuk para pengunjung yang berziarah dengan alas duduk berupa tikar untuk melakukan doa bersama dpimpin juru kunci. Pengunjung kebanyakan datang dari luar desa dengan maksud-maksud tertentu. Teras-3 terdapat beberapa fitur kubur dengan nisan batu tegak (menhir), dan tidak berjirat berada di bawah pohon angsana. Teras-2 berbentuk persegi empat tidak ditemukan fitur kubur. Teras-1 bagian luar kompleks sampai jalan desa berupa lereng bukit dengan tangga beton serta rimbun dengan tanaman bambu. Areal makam keseluruhan sangat gelap di kelilingi pohonpohon besar dan dikeramatkan.

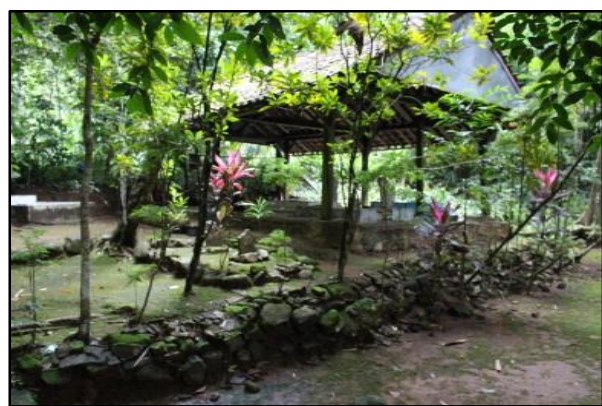

Gambar 11. Cungkup Petilasan Walisungsang di teras-4

(Sumber: Balai Arkeologi Bandung, 2015)

\section{Situs Buyut Jiwa}

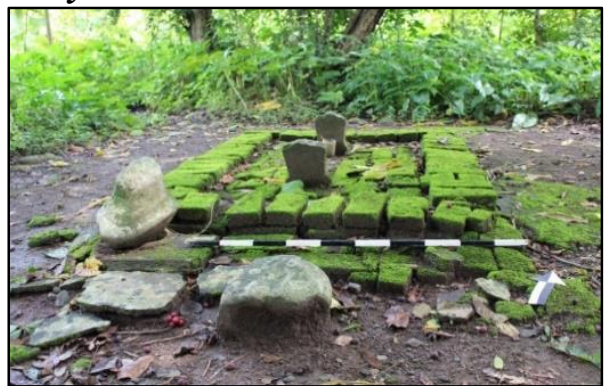

Gambar 12. Makam Buyut Jiwa, Desa Citenjo, Kec. Cibingbin

(Sumber: Balai Arkeologi Bandung 2015)

Situs Buyut Jiwa terdapat di Desa Citenjo, Kecamatan Cibingbin. Situs terletak jauh dari permukiman penduduk. Penanda makam di tandai dua nisan pipih berorientasi utara-selatan. Nisan bagian utara dan selatan mempunyai ukuran yang sama dengan tinggi 25 $\mathrm{cm}$, lebar $15 \mathrm{~cm}$ dan jarak antar nisan $82 \mathrm{~cm}$. Pada bagian badan nisan terdapat hiasan berupa lingkaran (mendalion), dan sulur-sulur. Jirat persegi empat dari susunan bata merah berukuran panjang $230 \mathrm{~cm}$ dan lebar $135 \mathrm{~cm}$. Disisi selatan terdapat batu datar yang di atasnya berdiri monolit berukuran tinggi $28 \mathrm{~cm}$, lebar dasar $25 \mathrm{~cm}$, lebar bagian puncak $10 \mathrm{~cm}$. Makam berada $100 \mathrm{~m}$ arah timur dari Sungai Cijangkelok. Buyut Jiwa adalah leluhur Desa Citenjo berperan sebagai penyebar Islam dan makamnya sering diziarah masyarakat sekitar dan dari luar desa. Di areal makam ditemukan tempat sesaji berupa gelas kaca yang berisi air.

\section{Situs Aki Buyut Tanu Maya}

Situs Aki Buyut Tanu Maya terdapat di Desa Cisaat, Kecamatan Cibingbin. Letak situs Aki Buyut Tanu Maya berada di sebelah selatan aliran Sungai Cibiawak. Penanda makam Aki Buyut Tanu Maya ditandai dua nisan batu tegak berorientasi utara-selatan. Batu tegak bagian utara berukuran tinggi $15 \mathrm{~cm}$. Lebar 15 $\mathrm{cm}$, dan batu tegak bagian selatan berukuran tinggi $19 \mathrm{~cm}$, dan lebar $15 \mathrm{~cm}$. Jarak antar batu $183 \mathrm{~cm}$. Makam diberi cungkup, dan dikelilingi pagar bambu dengan luas areal lahan $5 \times 5 \mathrm{~m}$. Makam dikeramatkan masyarakat sering dikunjungi peziarah.

Di areal makam banyak ditemukan sisa sesaji berupa gela-gelas plastik berisi kopi, piring, rokok, kelapa muda yang dibawa oleh peziarah. Di areal makam Aki Buyut Tanu Maya selalu dilakukan upacara persembahan yang dilakukan masyarakat setempat dengan membawa sesaji dan diakhiri makan bersama dipimpin tokoh atau ulama setempat.Aki Buyut Tanu Maya atau nama semula Maya Kerti adalah seorang Ngabeui atau kuwu pertama di Desa Dukuhbadag. Beliau orang yang sangat sakti, di segani semasa hidupnya.

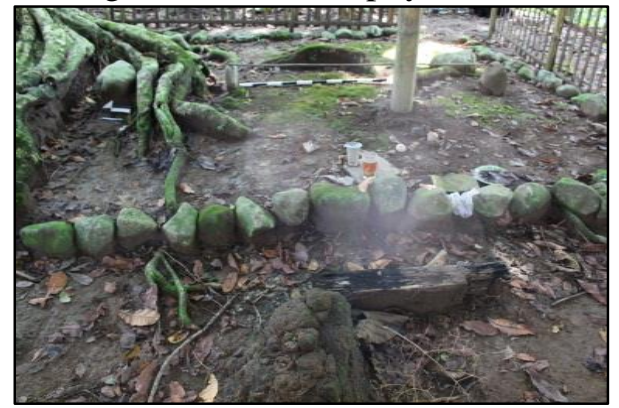

Gambar 13. Makam Aki Buyut Tanu Maya, Desa Cisaat, Kec. Cibingbin

(Sumber: Balai Arkeologi Bandung, 2015) 


\section{Situs Buyut Jaksa}

Situs Buyut Jaksa terdapat di Desa Bantarpanjang, Kecamatan Cibingbin. Makam terletak di permukiman penduduk, di areal tanah milik desa. Makam berada di bawah pohon kiara di areal tanah yang cukup tinggi dari tanah yang ada disekitarnya. Penanda makam ditandai dua nisan pipih berorientasi utara-selatan. Kedua nisan dalam kondisi patah, sedangkan jirat dari bahan bata berterap empat. Pada bagian badan nisan terdapat hiasan berupa lingkaran (mendalion), dan sulur-sulur. Lingkungan situs berada di sebelah barat bekas aliran sungai Cijangkelok yang sekarang telah menjadi lahan persawahan. Makam dikeramatkan oleh masyarakat sekitar, dan sering dikunjungi peziarah baik dari dalam desa maupun dari luar desa. Pada areal situs sering ditemukan sisa-sisa sesaji berupa kelapa muda, gelas berisi kopi, rokok dan lainnya.

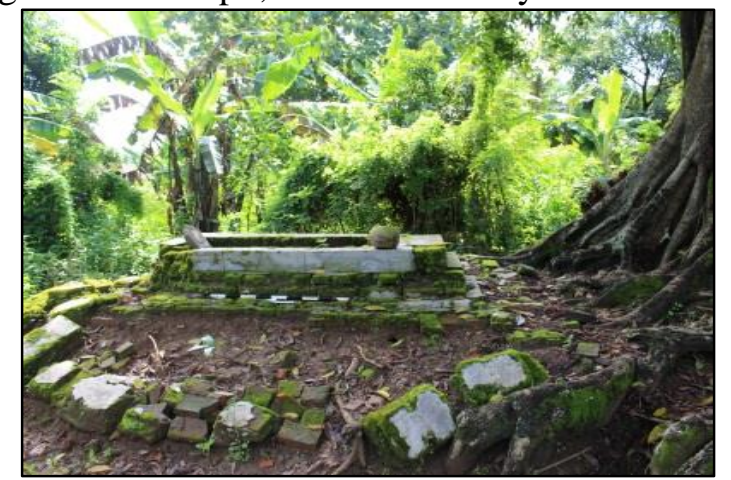

Gambar 14. Makam Buyut jaksa, desa bantar panjang

(Sumber: Balai Arkeologi Bandung, 2015)

\section{Situs Embah Buyut Panjang}

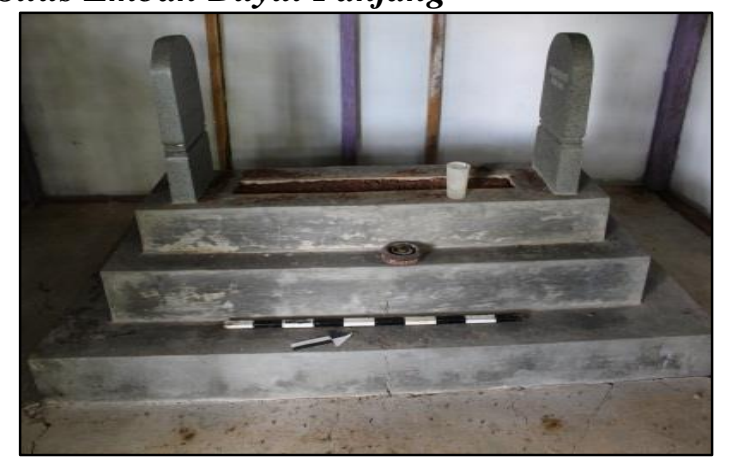

Gambar 15. Makam Buyut Panjang, Desa Bantar Panjang

(Sumber: Balai Arkeologi Bandung, 2015)

Situs Embah Buyut Panjang terletak di

Desa Bantarpanjang, Kecamatan Cibingbin . Situs merupakan makam berada jauh dari permukiman penduduk, terletak di areal tanah milik desa. Makam berada $100 \mathrm{~m}$ ke arah timur dari Sungai Cijangkelok. Makam ditandai 2 nisan, berorientasi utara-selatan. Menurut informasi awal makam hanya ditandai batu tegak dan batu-batu alam. Makam dikeramatkan oleh masyarakat setempat dan sering dikunjungi peziarah. Di areal makam ditemukan bekas sesaji yang di bawa peziarah.

\section{Religi dan Tradisi}

Pada hakekatnya kebudayaan adalah segala sesuatu yang dihasilkan oleh cipta, rasa, dan karsa manusia yang bersifat lahiriah ataupun rohaniah. Budaya suatu cara hidup yang berkembang dan dimiliki bersama oleh sekelompok orang dan diwariskan dari generasi ke generasi. Budaya terbentuk dari sejumlah unsur, termasuk sistem agama dan politik, adat istiadat, dan lainnya. Oleh karenannya budaya merupakan bagian tak terpisahkan dari diri manusia sehingga banyak orang cendrung menganggapnya diwariskan secara genitis (Saebani, 2012:162). Bagaimana dengan religi?, religi adalah bagian dari kebudayaan. Religi sudah berkembang di Indonesia sejak masa prasejarah. Kemunculan religi ditandai oleh perilaku-perilaku aktivitas religi dari komunitas yang hidup pada waktu itu, yang dibuktikan melalui sisa-sisa budaya materi yang ditinggalkannya. Pendapat Magetsari dalam makalahnya Religi Masa Pra Sriwijaya yang dikutip Rahyono, bahwa religi mencakup dua pengertian, yaitu (1) berkenaan dengan kepercayaan, dan (2) tindakan atau kebiasaan yang berkaitan dengan apa yang dipercaya. Hal dipercaya adalah sesuatu yang gaib berada diluar diri manusia memiliki kemampuan dan kekuatan yang melebihi dirinya ( 2009: 165).

Kemudian muncul pertanyaan, apakah tradisi? Tradisi berasal dari bahasa Latin tradition (riwayat, adapt, ajaran turun temurun, tradisi, warisan nenek moyang). Dalam bahasa Indonesia tradisi (adat) diartikan aturan (perbuatan dsb) yang lazim diturut atau dilakukan sejak dahulu kala (Leleno, 2005: 89). Tradisi erat kaitannya dengan kepercayaan atau agama (religi) dan kebudayaan (culture). Pengertian agama dalam konteks ini menyangkut bermacam-macam kepercayaan yang berkembang dalam masyarakat (relegionaturalis), seperti animisme (kepercayaan kepada arwah nenek moyang), dinamisme 
(kepercayaan pada kekuatan gaib), fetisme (kepercayaan kepada benda pusaka), spiritisme (kepercayaan kepada jiwa/spirit), dan magisme (kepercayaan kepada kekuatan gaib) (Lelono 2005: 89). Sebelum mengenal agama dan budaya yang masuk dari luar, masyarakat Indonesia telah mengenal budaya lokal atau agama asli. Sifat keaslian kala itu adalah "sifat lokal" yang berasal dari dan berkembang di daerah atau kawasan itu sendiri. Benda-benda, tumbuhan, tempat-tempat tertentu dipandang mempunyai kekuatan gaib yang ditempati makhluk halus berpengaruh penting pada kelangsungan hidup manusia (Istari, 2005: 98). Salah satu tradisi yang masih terus hidup dan berlangsung di tengah-tengah kehidupan masyarakat Indonesia sampai saat ini adalah ziarah makam.

Munculnya unsur religi dalam masyarakat Indonesia salah satunya melalui tradisi ziarah makam. Ziarah makam merupakan reaksi positif dari bentuk asimilasi religi dan tradisi. Tradisi ziarah berfungsi spiritual karena dalam pelaksanaannya selalu berhubungan dengan manusia untuk memohon keselamatan pada leluhur, roh halus dan tuhannya. Oleh karenanya sebagian masyarakat belum dapat meninggalkan tradisi ziarah makam. Tradisi ziarah makam tidak dapat dipisahkan dari religi. Berdasarkan pengumpulan data di lapangan, makam-makam kuna di wilayah Kuningan bagian timur bentuknya sangat sederhana, terdapat indikasi kuat penggunaan unsur lokal dalam penanda makam berupa nisan dan jirat. Penanda makam berupa nisan secara umum cendrung mempergunakan bahan batu-batu alam dengan bentuk tidak beraturan berupa batu tegak (menhir). Hanya beberapa makam tokoh saja yang telah memakai penanda nisan-nisan Islam kuna. Bila mengacu pada tipologi nisan yang ada pada makam Islam kuna di Indonesia menurut Lukman Nurhakim (1987:79-83), terbagi dalam empat gaya, yaitu gaya Aceh, gaya Demak Troloyo, gaya Bugis-Makassar, dan gaya Ternate-Tidore. Nisan Islam lainnya yang ditemukan di kawasan Cibingbin dan Cibeureum adalah tipe gaya Demak-Troloyo.

Fungsi menhir dalam alam kepercayaan masyarakat megalitik sebagai medium penghormatan, menjadi tahta kedatangan roh, sekaligus lambang dari orang-orang yang diperingati. Penggunaan menhir sebagai nisan kubur, menandai karakteristik Islam yang sangat akomodatif terhadap paham-paham lokal yang merupakan bentuk kepercayaan terhadap leluhur dan terus berlangsung hingga masa Islam (Handoko, 2014: 37). Menhir, sebagai pertanda adanya penguburan dapat dilihat di berbagai daerah. Wiyana (2008) mengatakan, bahwa pemberian tanda berupa menhir pada masa prasejarah, dan nisan pada masa Islam, secara prinsip mempunyai kesamaan, yaitu sebagai tanda adanya penguburan. Adanya kesamaan ini menimbulkan pemanfaatan fungsi, terutama dari fungsi atau bentuk menhir yang berfungsi sebagai tanda makam pada masa Islam (Wiyana,2008:311).

Berdasarkan data yang ada, kesederhanaan penanda makam berupa nisan batu tegak (menhir) terbuat dari bahan batu alam tanpa diolah, hal tersebut dapat terjadi di wilayah Kuningan bagian timur. Indikasi kuat lingkungan alam daerah tersebut termasuk kawasan pedalaman, perbukitan terjal dan bergelombang sehingga cukup sulit mendapat pengaruh budaya luar masa itu. Hal ini dapat berpengaruh pada perkembangan budaya khususnya pada bentuk ragam nisan-nisan makam di kawasan tersebut. Wiyana berpendapa, semakin berkurang suatu daerah melakukan kontak budaya dengan dunia luar, maka hiasan nisan yang dihasilkan kurang raya atau dinamis, karena masyarakat prasejarah lebih banyak mempengaruhinya dengan pola pikir sederhana (Wiyana, 1994: 12).

Berdasarkan data di lapangan, sebagian besar penempatan makam kuna di tempatkan pada lahan yang tinggi dan jauh dari pemukiman. Tradisi yang berasal dari masa pra Islam ini berlanjut sampai sekarang. Apabila pernyataan tersebut dikaitkan dengan pendapat menurut Sukendar, bahwa tempat yang tinggi merupakan tempat bersemayam arwah nenek moyang berkaitan dengan kepercayaan yang telah ada sejak masa pra-Islam (Sukendar, 1981: 85). Alasan lain pemilihan lokasi bangunan makam di gunung atau bukit ini tampaknya juga atas pertimbangan kesakralan tanahnya (Mustopo, 2001: 185). Dalam konsep religi gunung dan perbukitan simbol bersifat suci. Hal ini dilatari kepercayaan terhadap kekuatan supranatural oleh masyarakat megalitik. Masyarakat megalitik menganggap bahwa gunung merupakan tempat tinggal arwah 
leluhur. Kekuatan supranatural dianggap dimiliki oleh arwah nenek moyang yang tinggal di alam arwah. Oleh karena itu hubungan yang serasi antara manusia di dunia dengan arwah nenek moyang harus selalu dijaga. Cara menjaga hubungan baik itu dilakukan melalui upacara pemujaan terhadap kekuatan-kekuatan alam dan terhadap arwah leluhur. Lain halnya pendapat Ambary, bahwa peletakan makam orang yang dihormati di tempat yang tinggi semata-mata lebih cenderung disebabkan oleh penghargaan terhadap orang tersebut (Ambary, 1998: 100). Demikian halnya pada sebagian masyarakat kawasan penelitian, bahwa arwah nenek moyang yang telah meninggal, masih hidup terus di dunia arwah dan kehidupan mereka sangat dipengaruhi oleh bagaimana cara mereka memperlakukan arwah nenek moyangnya, salah satunya penempatan lokasi makam masih berpedoman pada tradisi ini.

Selain penggunaan unsur lokal pada makam-makam kuna di wilayah Kuningan bagian timur, sebagian masyarakatnya melakukan tradisi dan ritual di pemakaman. Masyarakat memohon doa restu kepada leluhur terutama bila ada keinginan untuk memperoleh suatu kebutuhan hidup. Bila akan bepergian jauh, dan akan melaksanakan suatu kegiatan baik secara pribadi maupun secara umum sebagian masyarakat meminta berkah dan keselamatan. Pada hari-hari tertentu sebagian masyarakat melakukan upacara dan ritual, diawali membersihkan makam, meletakkan sesaji (rokok, bunga, air, kopi, kelapa muda, telor asin, dan lainnya). Upacara dan ritual tersebut dipimpin sesepuh dan tokoh agama setempat. Ziarah ditutup dengan doa, dan diakhiri makan bersama.

Ternyata kegiatan religi dan tradisi bukan hanya pada makam-makam tokoh yang di kubur, petilasan (tapak-tapak) atau bangunan mirip makam juga termasuk keramat dan diziarah, hal tersebut terbukti pada situs Pasalisingan, situs Walangsungsang, Situs Langkoyang, dan situs Paserean. Menurut penuturan masyarakat maupun juru kunci, bahwa situs-situs petilasan tersebut dikeramatkan, dan di kunjungi peziarah, karena lokasi situs tersebut dahulunya pernah disinggahi para-para ulama atau tokoh-tokoh tertentu yang kharismatik. Hal tersebut menggambarkan religi sebagai tradisi yang berlanjut yang terus hidup dan berlangsung di tengah-tengah masyarakat penganut Islam hingga sekarang ini.

Kebiasaan mengunjungi makam merupakan pengaruh dari kebiasaan mengunjungi candi atau tempat suci lainnya dimasa dahulu dengan tujuan melakukan pemujaan terhadap roh nenek moyang (Mumfangati, 2007: 153). Penghormatan pada tokoh kharisma yang meninggal merupakan tradisi berdasarkan pola tradisional sebelum Islam, yakni adanya kesan pemujaan kepada arwah nenek moyang (Ambary, 1998: 201). Arwah leluhur dapat bersikap baik atau buruk tergantung bagaimana manusia yang masih hidup memperlakukannya. Oleh karenanya, membina hubungan serasi antara manusia di dunia dengan arwah nenek moyang harus selalu dijaga. Untuk menjaga hubungan baik tersebut salah satunya melalui upacara pemujaan terhadap kekuatan-kekuatan alam dan terhadap arwah leluhur (Prasetyo, 2004: 162). Upacara dan ritus merupakan pengungkapan perasaan hati ketika berhubungan dengan substansi yang dipercayai dan merupakan simbol (Andayani, 2004: 2).

Motivasi peziarah berkunjung ke makam pada dasarnya merupakan salah satu rangkaian kegiatan religius. Berziarah atau mengunjungi makam merupakan suatu upaya untuk mendoakan dan mencari berkah dari Allah SWT. Sehingga sudah menjadi kewajiban masyarakat, bahwa makam leluhur dan makam tokoh penyebar Islam beserta pengikutnya dikeramatkan dan diziarah sebagai rasa hormat dan ucapan terimakasih pada leluhurnya. Apabila alasan tersebut dikaitkan denga proses kedatangan atau penyebaran Islam di wilayah Kuningan bagian timur maka dapat diterima. Setelah kedatangan Sunan Gunung Jati meng Islamkan kawasan Luragung-Kuningan, penyebaran Islam di pedalaman dan perbatasan Kuningan selanjutnya diteruskan oleh para ulama yang di datangkan dari Cirebon, ulama lokal atau kepala-kepala daerah masing-masing yang sudah masuk Islam.

Selanjutnya, untuk memperdalam penguasaan ilmu agama Islam bagi masyarakat muslim yang ada di pedalaman, salah satunya wilayah Kuningan bagian timur didatangkan sejumlah ulama sebagai juru dakwah penyebar Islam, di antaranya: Pangeran Purwajaya, Pangeran Purwaganda dan Syekh Dako dari Cirebon (Ekadjati, 2003: 55-59). Kemudian 
muncul pula keberadaan tokoh/ulama lokal yaitu, Eyang Hasan Maulani atau Eyang Menado masih di kawasan GarawangiKuningan (Latifundia, 2014: 5-6). Para tokoh/ulama tersebut diakui menurunkan ulama-ulama lainnya di kawasan pedalaman Kuningan termasuk wilayah Kuningan bagian timur yaitu kecamatan Cibingbin dan Cibeureum. Sehingga menjadi kewajiban masyarakat setempat, bahwa makam tokoh dan pengikutnya dikeramat dan diziarah sebagai rasa hormat dan terimakasih pada leluhurnya.

Hal tersebut menggambarkan sikap dari emosi keagamaan (religius emotion) mendorong diri seseorang melakukan ziarah makam yang dikeramatkan. Mengacu kepada pernyataan Koentjaraningrat, bahwa emosi keagamaan adalah sebagai suatu getaran menghinggapi seseorang dalam hidupnya, walau hanya sesaat. Emosi keagamaan ada dibelakang setiap kelakuan serba religi, sehingga menyebabkan timbulnya sikap keramat, baik pada kelakuan manusia itu sendiri, maupun pada tempat kelakuan itu diungkapkan (Rosmana, 2009:244). Melalui emosi keagamaan manusia berusaha memusatkan dirinya pada alam sakral untuk memohon kepada Allah SWT dengan mengunjungi tempat yang diyakini sebagai orang suci. Manusia berharap dalam melakukan ziarah makam ada berkah yang dapat terkabul dari segala permohonan yang dipanjatkan, dan dapat menimbulkan pengaruh tertentu pada dirinya. Dengan berziarah diharapkan ketauladanan ahli kubur masa hidupnya dapat diteruskan oleh generasi berikutnya.

Selain itu, dalam kehidupan masyarakat muncul persepsi yang menyatakan bahwa setiap makam keramat memiliki perbawa atau berkah masing-masing. Ada perbawa keberuntungan dalam bidang kesuksesan usaha, perdagangan, keselamatan, kepemimpinan (jabatan dalam pemerintahan), jodoh, dan lain-lain. Peziarah meyakini bahwa makam keramat merupakan tempat untuk melakukan, tafakur atau tempat spiritual. Untuk itu, tidak dapat dipastikan tujuan pengunjung untuk ziarah makam dengan berbagai niat dan maksud, apakah berziarah mendoakan para leluhur atau memuja para leluhur. Dalam Islam tidak menolak tradisi atau budaya yang berkembang di tengah-tengah masyarakat pendukungnya, selama tidak bertentangan dengan ajaran Islam yang tertuang dalam Al-Quran dan hadis Nabi SAW.

Bagi individu atau masyarakat yang memiliki motivasi lain dalam tujuan berziarah itu bertentangan dengan ajaran Islam karena dianggap menyekutukan Tuhan. Maksud motivasi lain adalah jika meminta sesuatu kepada yang ada dalam makam, baik itu makam wali, aulia ataupun siapa saja meminta selain kepada Allah hukumnya haram dan musyrik (Hermana, 2000: 289). Dalam Islam tidak mengharamkan tradisi-tradisi yang berlaku sebelum agama Islam berkembang di suatu kawasan, wilayah selama tidak bertentangan dengan ajarannya.

\section{KESIMPULAN}

Penanda makam nisan ditandai batu tegak/menhir menggambarkan kuatnya unsur lokal, secara aktual menunjukkan kelanjutan dari tradisi megalitik, meskipun Islam sudah berkembang dan dianut mayoritas masyarakat kawasan Cibingbin dan Cibeureum wilayah Kuningan bagian timur.

Fenomena pola keletakan makam di perbukitan, penempatan situs jauh dari pemukiman, situs di areal punden berundak, penanda makam bentuk menhir (batu tegak) sebagai nisan, upacara dan ziarah makam, hal ini menggambarkan kehidupan religi tradisi pra Islam. Sebagian masyarakat mengkeramatkan makam dan petilasan. Makam keramat merupakan salah satu tempat yang sakral, tempat tafakur, tempat yang tepat mengutamakan kehidupan spiritual yang dapat memberikan harapan hidup lebih baik. Meskipun telah bersentuhan dengan Islam, namun kepercayaan lokal terus bertahan dan hidup.

Faktor lingkungan alam wilayah Kabupaten Kuningan bagian timur berada di pedalaman dan perbukitan yang cukup sulit dijangkau, hal ini mengakibatkan transisi Islam sangat lambat berkembang. Akibatnya unsur budaya lokal cenderung pra Islam sulit atau bahkan mungkin tak bisa dihilangkan. Semakin kurang suatu wilayah masyarakatnya melakukan kontak budaya dengan dunia luar, masyarakat pra sejarah lebih banyak mempengaruhinya dengan pola pikir sederhana.

Dapat disimpulkan bahwa religi masa Islam yang di tinjau dari aspek makam-makam kuna, menunjukkan adanya unsur penghormatan kepada leluhur. Secara esensial 
bentuk-bentuk penghormatan pada leluhur, pada tokoh yang pernah ada merupakan kelanjutan tradisi sebelumnya yaitu masa praIslam.

\section{Ucapan Terima Kasih}

Penulis menyampaikan terimakasih kepada: Kepala Dinas Pariwisata dan Kebudayaan Kabupaten Kuningan. Kepala Bidang Kebudayaan dan staf; Bapak Camat Kecamatan Cibingbin dan unsur semua kepala desa; Bapak Camat Kecamatan Cibereum beserta unsur seluruh kepala desa; Dra. Sudarti, M. Hum Peneliti Balai Arkeologi Bandung, dan pihak-pihak lain yang tidak dapat disebut satu persatu atas bantuan dan dukungannya selama penelitian hingga tulisan ini dapat disajikan.

\section{$* * * * *$}

\section{DAFTAR PUSTAKA}

Adeng. (2012). Cingcowong Upacara Meminta Hujan Pada Masyarakat Kuningan. Bandung: Balai Pelestarian Nilai Budaya (BPNB) Bandung.

Ambary, Hasan Muarif. (1991). Makam-makam Kesultanan dan Parawali Penyebar Islam di Pulau Jawa. Dalam Aspek-aspek Arkeologi Indonesia No. 12. Jakarta: Pusat Penelitian Arkeologi Nasional.

Ambary, Hasan Muarif. (1998). Menemukan Peradaban, Jejak Arkeologis dan Historis Islam Indonesia. Jakarta: Logos Wacana Ilmu.

Andayani, Ria. (2004). Makna ritus Pada Upacara Karian di Kampung Banceuy Kabupaten Subang. Bandung: Balai Kajian Sejarah dan Nilai Tradisional Bandung.

Ekadjati, Edi S. (2003). Sejarah Kuningan dari Masa Prasejarah Hingga Terbentuknya Kabupaten. Bandung: PT Kiblat Buku Utama.

Hafid, Abdul. (2013). Sitem Kepercayaan pada Komunitas Adat Kajang Desa Tanah Towa, Kecamatan Kajang, Kabupaten Bulukumba. Patanjala 5(1): 1-19.

Handoko, Wuri. (2014). Tradisi Nisan Menhir pada Makam Kuno Raja-Raja di Wilayah Kerajaan Hitu. Kapata Arkeologi 10(1): 33-46.

Hermana. (2009). Budaya Spiritual Syekh Aulia Abdul Gapur. Dalam Patanjala, 1(3): 283295.

Koentjaraningrat. (1984). Kebudayaan Jawa. Jakarta: Balai Pustaka.

Latifundia, Effie. (2015). Penelitian Arkeologi Tentang Budaya Islam Di Perbatasan Jawa Barat-Jawa Tengah. Laporan Penelitian
Arkeologi. Bandung. Balai Arkeologi Bandung.

Latifundia, Effie. (2014). Struktur makam Kuna Islam di Kawasan Luragung kabupaten kuningan. Purbawidya 3(1): 53-64.

Lelono, Hari T.M. (2005). Sistem Masyarakat Jawa Kuna Pada Masa Majapahit Akhir. Dalam Jurnal Peneliti Arkeologi Vol. 5. hlm 86-95. Yogyakarta: Balai Arkeologi Yogyakarta.

Mumfangita, Titi. (2007). Tradisi Ziarah Makam Leluhur Pada Masyarakat Jawa. Makna, Tradisi dan Simbol II (3): 152-159.

Mustopo, Moehammad Habib. (2001). Kebudayaan Islam di Jawa Timur Kajian Beberapa Unsur Budaya Masa Peralihan. Yogyakarta: Jendela Grafika.

Nurhakim, Lukman. (1990). Tinjauan Tipologi Nisan Pada Makam Islam Kuna di Indonesia.Dalam Analisis Hasil Penelitian Arkeologi I. hlm. 75-84. Jakarta: Pusat Penelitian Arkeologi Nasional.

Prasetyo, Bagyo, dkk. (2004). Religi Pada Masyarakat Prasejarah Di Indonesia. Jakarta: Puslit Arkenas.

Radam, Noerid Haloei. (2001). Religi Orang Bukit. Yogyakarta : Yayasan Semesta.

Rahyono, F.X. (2009). Kearifan Budaya Dalam Kata. Jakarta: Wedatamawidyasastra.

Rosmana, Tjetjep. (2009). Budaya Spiritual: Persepsi Peziarah pada Makam Keramat Leluhur Sumedang. Patanjala 1(3): 243-257.

Saebani, Beni Ahmad. (2012). Pengantar Antropologi. Bandung: CV Pustaka Setia.

Sukendar, Haris. (1981). Peninggalan Tradisi megalitik di daerah Cianjur, Jawa Barat. Jakarta: Pusat Penelitian Arkeologi Nasional.

Wiyana, Budi. (2008). Dari Menhir ke Nisan : Suatu Dinamika Budaya. Kumpulan Makah Pertemuan Ilmiah Arkeologi. Kediri, 23-28 Juli 2002. Jakarta. IAAI. 